\title{
Macro-turbulent characteristcs of pressures in hydraulic jump formed downstream of a stepped spillway
}

\section{Características macroturbulentas das pressões em um ressalto hidráulico formado a jusante de um vertedouro em degraus}

\author{
Carolina Kuhn Novakoski ${ }^{1}$, Eliane Conterato ${ }^{2}$, Marcelo Marques ${ }^{1}$, Eder Daniel Teixeira ${ }^{1}$, \\ Guilherme Abud Lima ${ }^{1}$ and Alexandre Mees ${ }^{1}$
}

${ }^{1}$ Universidade Federal do Rio Grande do Sul, Porto Alegre, RS, Brazil

${ }^{2}$ Fundação Universidade Federal de Rondônia, Porto Velho, RO, Brazil

E-mails: carolkn04@gmail.com (CKN), eliconterato@gmail.com (EC), mmarques@iph.ufrgs.br (MM), eder.teixeira@ufrgs.br (EDT), abudgui@hotmail.com (GAL), alexandremees@gmail.com(AM)

\begin{abstract}
Stilling basins are structures built at the base of the spillway to dissipate energy, by means of a hydraulic jump. Hydraulic jump is a turbulent phenomenon that causes large pressure fluctuation in the stilling basin bottom, and can damage the sink structure through mechanisms such as fatigue, upflit pressure and cavitation. The use of stepped spillways allows the dissipation of a parcel of the energy while the water falls by the spillway, allowing a reduction in the stilling basin's dimensions and cost. The present article presents the analysis of the longitudinal distribution of mean pressure, pressure fluctuations, skewness coefficient and kurtosis coefficient, derived from tests on physical hydraulic models. Pressure values measured in a stilling basin downstream of a stepped spillway (for Froude numbers between 5 and 8) were compared with data observed in a stilling basin downstream of a smooth spillway with a radius of concordance between the chute and the basin (for Froude numbers between 4.5 and 10). The results of these studies show that the mean pressures and the pressure fluctuation observed in the stilling basin downstream of stepped spillway present maximum values at the spillway's closest point, differing, thus, from those at the smooth spillway. The longitudinal distribution of skewness and kurtosis coefficients enabled to define the positions for flow detachment start, roller ending and as well as the ending of the influence of the hydraulic jump over the flow.
\end{abstract}

Keywords: Stepped spillway; Stilling basin; Hydraulic jump.

\section{RESUMO}

A bacia de dissipação tem como finalidade dissipar, através de ressalto hidráulico, a energia do escoamento junto à base do vertedouro. Por ser um fenômeno turbulento que provoca amplas flutuações de pressão junto ao fundo da bacia, o ressalto hidráulico pode comprometer a estrutura do dissipador por mecanismos como fadiga, subpressão e cavitação. A utilização de vertedouros em degraus permite a dissipação de uma parte da energia ainda durante o escoamento da água pela calha, o que possibilita a redução das dimensões e do custo da estrutura da bacia de dissipação. O presente artigo apresenta a análise das distribuições longitudinais da pressão média, das flutuações de pressão e dos coeficientes de assimetria e curtose, oriundas de ensaios realizados em modelos físicos hidráulicos. Foi feita uma comparação das características das pressões obtidas em uma bacia de dissipação a jusante de um vertedouro em degraus (para números de Froude entre 5 e 8) com dados observados em uma bacia de dissipação a jusante de um vertedouro de calha lisa, com raio de concordância entre a calha e a bacia (para números de Froude compreendidos entre 4,5 e 10). A partir dessa análise pode-se concluir que, diferentemente do ocorrido na bacia de dissipação com calha lisa, as pressões médias e flutuações de pressão observadas na bacia de dissipação a jusante de calha em degraus tem seu máximo no ponto mais próximo ao pé do vertedouro. O desenvolvimento longitudinal dos coeficientes de assimetria e curtose possibilitaram determinar as posições de início do descolamento do escoamento, de fim do rolo e de fim da influência do ressalto hidráulico no escoamento.

Palavras-chave: Bacia de dissipação; Ressalto hidráulico; Vertedouro em degraus. 


\section{INTRODUCTION}

The use of a stepped spillway allows the dissipation of a significant amount of upstream energy along the chute, reducing the resulting energy at the base of the spillway if compared to the same energy in a smooth chute spillway. Therefore, one of the advantages of the stepped spillway is the reduction of the dimensions of the dissipation structure downstream of the chute.

Peterka (1957) and Simões (2008) indicate that a smooth chute can dissipate up to $5 \%$ of upstream energy. Several studies carried out with stepped spillways present values for this dissipation of energy that are this extremely larger. For example, the Tozzi (1992) experiments indicated a relation between the residual energies in smooth chutes and stepped chutes ranging from 40 to $66 \%$ and, for the studies of Sanagiotto (2003), energy dissipation in stepped chutes in relation to smooth chutes reached values between 45 and $94 \%$.

According to Peterka (1957), a stilling basin where a hydraulic jump is formed downstream of a spillway is classified as a type I basin. According to Schulz et al. (2015), the hydraulic jump can be described as the result of a shock between the subcritical and supercritical flows, resulting in a zone with circular movements (roller). This phenomenon generates great swells, fluctuations of pressure and velocity and can cause damage to the structure. The knowledge of the geometric characteristics of the hydraulic jump is fundamental for the elaboration of the design of the dissipation structures. One of the most studied geometric characteristics is the length of the hydraulic jump due to a high level of imprecision. Peterka (1957) define the end of the hydraulic jump as the section immediately downstream of the roller. Marques, Drapeau and Verrette (1997) and Teixeira (2003) devised the Equations 1 and 2 for calculating the length of the hydraulic jump, respectively. For the length of the roller, Marques, Drapeau and Verrete et al. (1997) devised the Equation 3.

Other parameters that must be known for an adequate design of the dissipation structures are the longitudinal distributions of mean pressure, pressure fluctuation, skewness and kurtosis coefficients. Marques, Drapeau and Verrette (1997) presented experimental results obtained for these parameters measured in a stilling basin downstream of smooth chute spillway with a radius of concordance between the spillway and the channel bottom. In this study the hydraulic jump was positioned so that its beginning coincided with the point of tangency between the radius of concordance of the spillway and the bottom of the channel. In this same line of positioning of the hydraulic jump, other studies were developed, such as Mees (2008), who studied the effects of the hydraulic jump in a type I stilling basin for low numbers of Froude, and Conterato (2014), who studied the effects of the phenomenon in a stilling basin with terminal sill downstream of a stepped spillway.

The present paper presents the results observed in a stilling basin downstream of a stepped spillway and compares them with those observed by Marques, Drapeau and Verrette (1997).

$$
L_{j}=8.5\left(Y_{l}-Y_{r}\right)
$$

$L_{j}=8.0\left(Y_{l}-Y_{r}\right)$

$$
L_{r}=6.0\left(Y_{l}-Y_{r}\right)
$$

Where $L_{j}=$ hydraulic jump lenght; $y_{r}=$ fast conjugate height; $y_{l}=$ slow conjugate height; $L_{r}=$ lenght of the roller.

\section{THE MODEL AND THE EQUIPMENT}

Next, the characteristics of the physical model used to obtain the instantaneous pressure data in the stilling basin downstream of the stepped spillway are described, as well as the characteristics of the physical model used by Marques, Drapeau and Verrette (1997) for stilling basin measurements downstream of smooth chute.

\section{Physical model of the stilling basin downstream of a stepped spillway}

The research was developed in a reduced partial model of a stepped spillway with downstream stilling basin. The model consists of a chute with a slope of $1 \mathrm{~V}: 0.75 \mathrm{H}$ (53.13), height of $2.45 \mathrm{~m}$, width of $0.40 \mathrm{~m}$ and has steps with a height of $6 \mathrm{~cm}$. Downstream of the chute there is a horizontal channel $1.20 \mathrm{~m}$ high, approximately $8 \mathrm{~m}$ long and $0.40 \mathrm{~m}$ wide. To allow visualization of the flow, $5 \mathrm{~m}$ of channel length have acrylic walls. Downstream of the channel, a vertical shutter-type floodgate combined with a graduated scale piezometric tube allow level control and verification. Upstream of the stepped chute, a $5 \mathrm{~m}$ long segment was built as well as a small reservoir to tranquilize the flow. The channel admits a specific flow of approximately $0.3 \mathrm{~m} 2 / \mathrm{s}$, which corresponds to a depth of water of approximately $0.27 \mathrm{~m}$. A simplified schematic of the model is shown in Figure 1.

To measure the pressures, transducers of the brand Sitron, model SP96 were used, installed in 20 distinct points, distanced from the end of the stepped chute. The transducers were installed with a screwabble support placed under the bottom of the channel, thus possible distortion effects of the pressure signal due to the connection with hoses are eliminated. Figure 2 shows a schematic of the installation of the transducers.

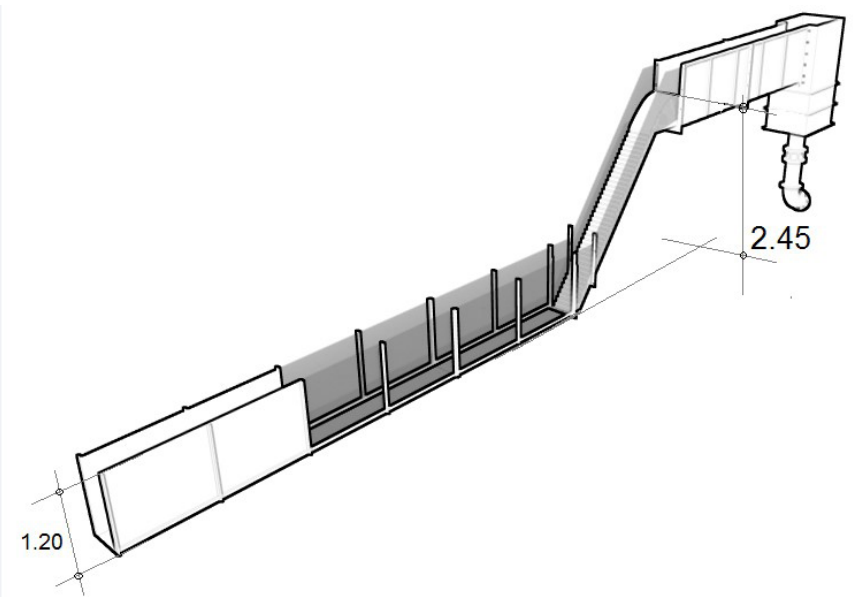

Figure 1. Schematic of the stepped spillway and the stilling basin. 


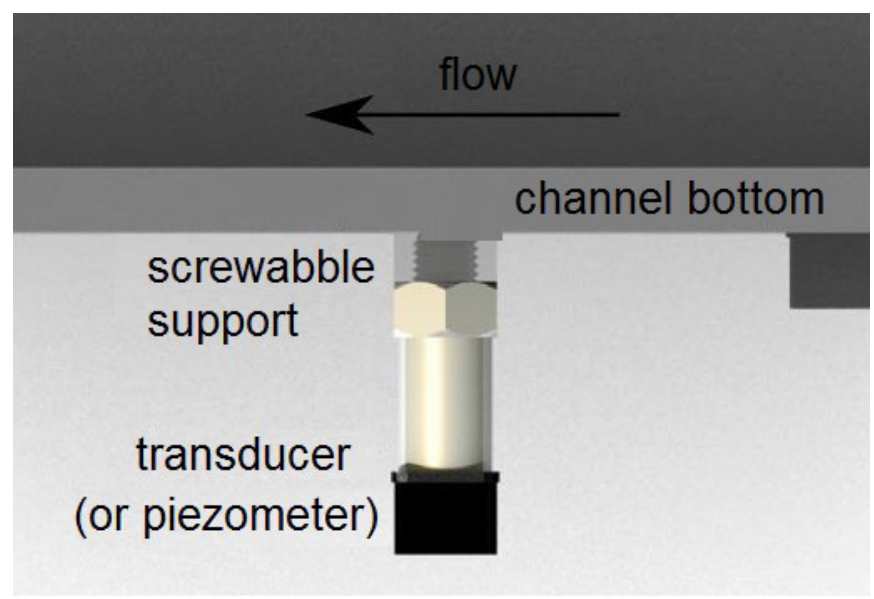

Figure 2. Schematic of transducer installation.

Of the 20 transducers used, 10 have a working range of -1.5 to $1.5 \mathrm{mH} 2 \mathrm{O}$ and 10 have a range of -1.5 to $3.0 \mathrm{mH} 2 \mathrm{O}$. Transducer signals were passed to na analog digital converter of the brand National Instruments, model USB-6225, with digital resolution of 16 bits and admissible voltage range of -10 to $10 \mathrm{~V}$. All the tests were carried out with a duration of 15 minutes and a frequency of $128 \mathrm{~Hz}$, which generated 115200 sample points. Table 1 shows the distances, from the end of the stepped chute, and the transducer range for each tapping point.

\section{Physical model of the stilling basin downstream of smooth chute spillway}

The model used by Marques, Drapeau and Verrette (1997) consists of a Creager spillway with a height of $720 \mathrm{~mm}$ installed in a channel with a width of $600 \mathrm{~mm}$. The authors obtained the pressure data through 22 transducers of the brand Omega, model PX800-005GV, installed externally to the channel. The taps were attached to the transducers through silicone hoses of $6.4 \mathrm{~mm}$ in diameter and $500 \mathrm{~mm}$ in length, following the recommendations of Lopardo and Henning (1986). The data was obtained with $50 \mathrm{~Hz}$ frequency in measurements lasting $200 \mathrm{~s}$.

\section{METHODOLOGY OF TESTS}

The tests carried out in the stilling basin downstream of the stepped spillway were performed with five different flow rates: 40 , 60, 80, 100 and $110 \mathrm{~L} /$ (s.m). The maximum flow rate was limited in order to avoid channel overflow and minimum flow, by the accuracy of the electromagnetic flow meter, which allows measuring only flows above $40 \mathrm{~L} / \mathrm{s}$. Table 2 presents the characteristics of the tests and Figure 3 shows the parameter definition.

$\frac{y_{l}}{y_{r}}=\frac{1}{2}\left(\sqrt{1+8 F_{r}^{2}}-1\right)$

$$
F_{r}=\frac{v_{r}}{\sqrt{y_{r} \times g}}
$$

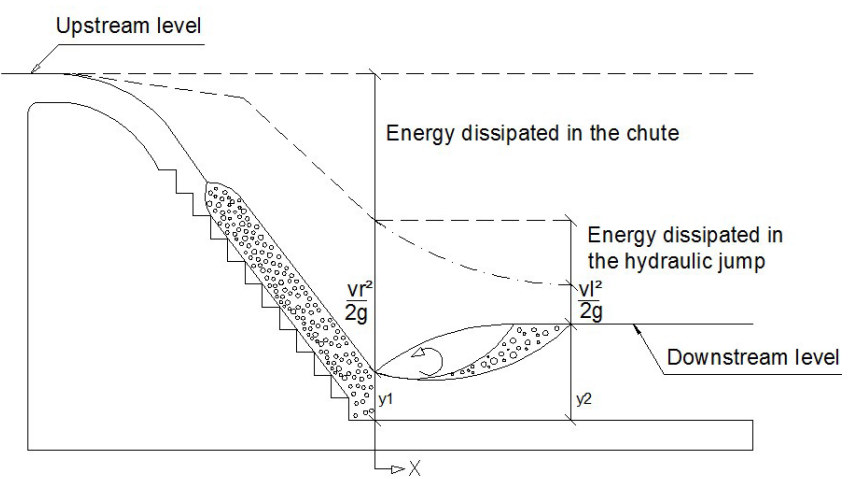

Figure 3. Description of parameters.

Table 1. Distances and ranges of the transducers for each pressure tapping point.

\begin{tabular}{ccc}
\hline Tapping point & $\begin{array}{c}\text { Distance } \\
(\mathbf{c m})\end{array}$ & $\begin{array}{c}\text { Transducer range } \\
\left(\mathbf{m H}_{2} \mathbf{O}\right)\end{array}$ \\
\hline 1 & 17.4 & -1.5 to 3.0 \\
2 & 27.4 & -1.5 to 3.0 \\
3 & 37.4 & -1.5 to 3.0 \\
4 & 53.8 & -1.5 to 3.0 \\
5 & 64 & -1.5 to 3.0 \\
6 & 73.9 & -1.5 to 3.0 \\
7 & 84.4 & -1.5 to 3.0 \\
8 & 103.8 & -1.5 to 3.0 \\
9 & 114 & -1.5 to 3.0 \\
10 & 129.2 & -1.5 to 3.0 \\
11 & 138.2 & -1.5 to 1.5 \\
12 & 169.4 & -1.5 to 1.5 \\
13 & 199.6 & -1.5 to 1.5 \\
14 & 229.4 & -1.5 to 1.5 \\
15 & 269.5 & -15 to 1.5 \\
16 & 300.5 & -1.5 to 1.5 \\
17 & 330.5 & -1.5 to 1.5 \\
18 & 365 & -1.5 to 1.5 \\
19 & 400 & -1.5 to 1.5 \\
20 & 435 & -1.5 to 1.5 \\
\hline
\end{tabular}

Table 2. Characteristics of the test perfomed in stilling basin downstream of a stepped spillway.

\begin{tabular}{cccccc}
\hline $\mathbf{Q}(\mathbf{L} / \mathbf{s})$ & $\begin{array}{c}\mathbf{y}_{\mathbf{r}} \\
(\mathbf{m m})\end{array}$ & $\begin{array}{c}\mathbf{v}_{\mathbf{r}} \\
(\mathbf{m} / \mathbf{s})\end{array}$ & $\begin{array}{c}\mathbf{y}_{\mathbf{1}} \\
(\mathbf{m m})\end{array}$ & $\mathbf{F r}$ & $\begin{array}{c}\mathbf{R e} \\
(\mathbf{x} 1000)\end{array}$ \\
\hline 40 & 26.4 & 3.78 & 265 & 7.44 & 100 \\
60 & 36.11 & 4.15 & 339 & 6.98 & 150 \\
80 & 44.05 & 4.54 & 409 & 6.91 & 200 \\
100 & 54.15 & 4.62 & 459 & 6.34 & 250 \\
110 & 60.01 & 4.58 & 478 & 5.98 & 275 \\
\hline
\end{tabular}

$R_{e}=\frac{v_{r} \times y_{r}}{v}$

Where $\mathrm{Q}=$ flow, $v_{r}=$ mean velocity in the section of the fast conjugate height; $F_{r}=$ Froude number of the supercritical flow of the hydraulic jump; $R_{e}=$ Reynolds number of the supercritical flow of the hydraulic jump; $g=$ acceleration of gravity; $v=$ kinematic viscosity of the fluid. 
The test was performed with free hydraulic jump. Thus, the downstream level $(\mathrm{Nj})$ must be equal to the slow conjugate height, so the hydraulic jump was positioned at the beginning of the straight section of the stilling basin. The values of $y_{l}$ were measured during the experiments, whereas the values of $y_{r}$ were calculated using the equation of Belanger (Equation 4). The Froude and Reynolds numbers were calculated through Equations 5 and 6, respectively. Figure 4 shows the runoff for the flow rate of $80 \mathrm{~L} / \mathrm{s}$.

With the data obtained from the tests performed it was possible to analyze the longitudinal distribution of mean pressure, standard deviation, skewness and kurtosis coefficients and compare them with the same analyzes performed by Marques, Drapeau and Verrette (1997).

Marques, Drapeau and Verrette (1997) performed their tests, also, with free hydraulic jump. Table 3 presents the characteristics of the these tests.

\section{MEAN PRESSURE}

The mean pressure data were presented as a function of the position of the hydraulic jump according to Equation 7, as suggested by Marques, Drapeau and Verrette (1997).

$$
\frac{P_{x}-y_{r}}{y_{l}-y_{r}}=f\left(\frac{x}{y_{l}-y_{r}}\right)
$$

Table 3. Characteristics of the tests in stilling basin downstream of smooth chute spillway.

\begin{tabular}{cccccc}
\hline $\mathbf{Q}(\mathbf{L} / \mathbf{s})$ & $\begin{array}{c}\mathbf{Y}_{\mathbf{r}} \\
(\mathbf{m m})\end{array}$ & $\begin{array}{c}\mathbf{V}_{\mathbf{r}} \\
(\mathbf{m} / \mathbf{s})\end{array}$ & $\begin{array}{c}\mathbf{Y}_{\mathbf{1}} \\
(\mathbf{m m})\end{array}$ & $\mathbf{F}_{\mathbf{r}}$ & $\begin{array}{c}\mathbf{R e} \\
(\mathbf{x} 1000)\end{array}$ \\
\hline 35 & 16 & 3.67 & 186 & 9.3 & 59 \\
48 & 22 & 3.72 & 218 & 8.1 & 82 \\
63 & 28 & 3.76 & 247 & 7.2 & 102 \\
87 & 38 & 3.83 & 301 & 6.3 & 147 \\
127 & 54 & 3.92 & 373 & 5.4 & 212 \\
163 & 68 & 4.00 & 426 & 4.9 & 272 \\
\hline
\end{tabular}

Where $P_{x}=$ mean pressure at the point $\mathrm{x}$ in meters of depth of water, $\mathrm{x}=$ distance from the transducer to the start point of the stilling basin.

Figure 5 presents the gross values obtained for the mean pressure in the tests performed and Figure 6 presents the obtained curves, dimensionless according to Equation 7, compared to those obtained by Marques, Drapeau and Verrette (1997).

Analyzing Figure 5 it shows that the values of gross mean pressure increase with Froude number. It is observed that the greater pressure variation occurs in the zone of impact of the jet in the basin because of the absence of curvature.

From Figure 6 it can be asserted that all the conditions tested in the present study show a similar pattern. The values obtained for the point nearest to the spillway, where the impact of the water jet in the stilling basin occurs, are higher than those observed in Marques, Drapeau and Verrette (1997) to the same point. This fact occurs due to the presence of radius of acordance between spillway and stilling basin in the study of the authors, which significantly reduces the pressure at the beginning of the basin. After this, an abrupt reduction in pressure occurs to approximately the position of $1\left(y_{l}-y_{r}\right)$. From this point on the data obtained for the present study show a similar pattern to the data obtained by Marques, Drapeau and Verrette (1997), increasing with approximately the same gradient to the position of about $4\left(y_{l}-y_{r}\right)$. This zone in which the values of the mean pressures increase with the same gradient is represented in Figure 6 as zone 1 . Thereafter, the mean pressure continues to increase, however, more smoothly, to the approximate distance of 8.5 $\left(y_{l}-y_{r}\right)$ (zone 2). From this point on the values begin to oscillate until they become practically constant (zone 3).

\section{PRESSURE FLUCTUATION}

For the pressure fluctuation analysis, the relation presented in Equation 8 was used to group the data into a single curve. Figure 7 presents the gross values obtained for the standard deviation in the tests performed and Figure 8 presents the

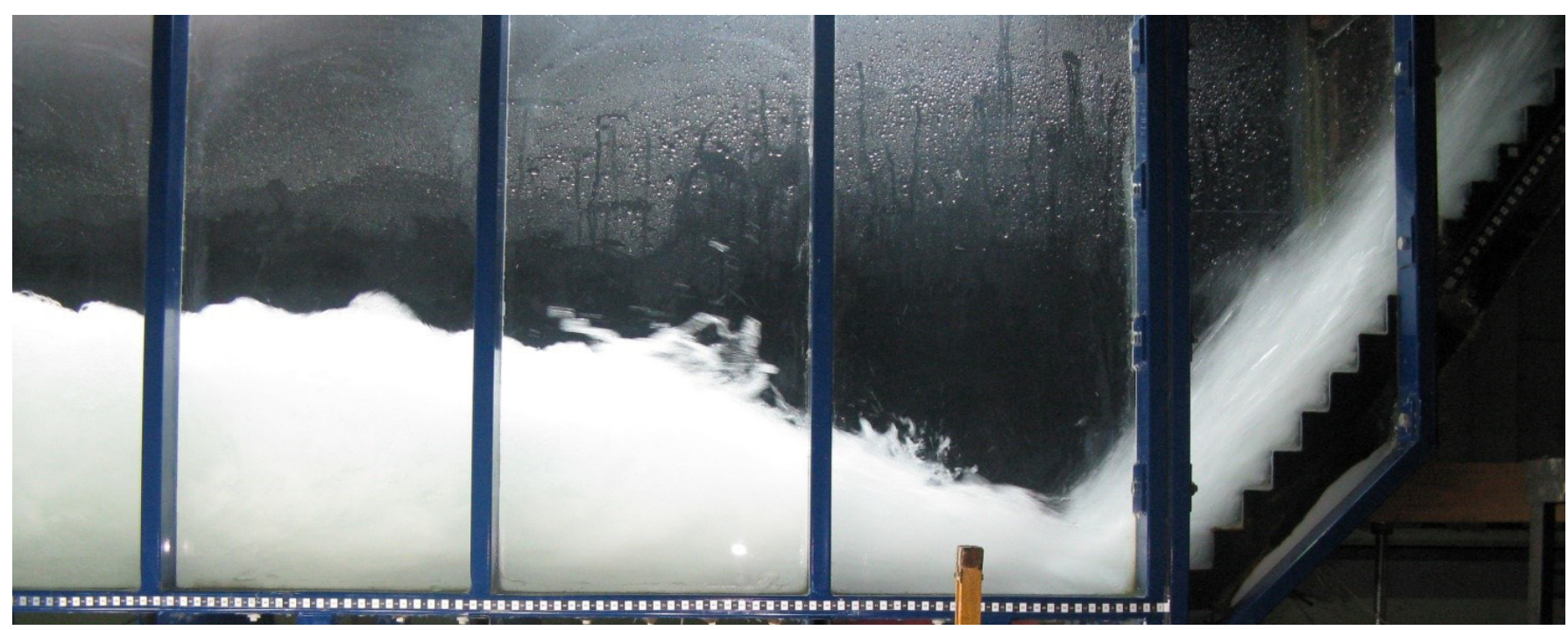

Figure 4. Runoff for the flow of $80 \mathrm{~L} / \mathrm{s}$. 


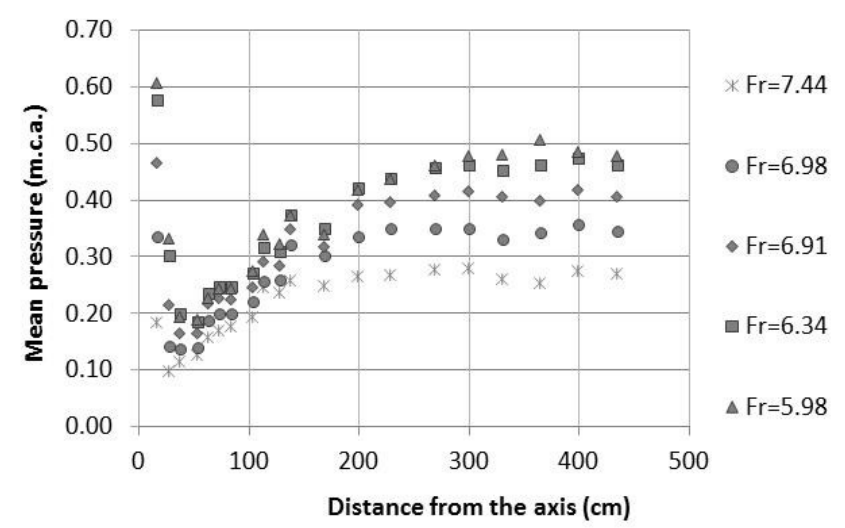

Figure 5. Gross mean pressure data.

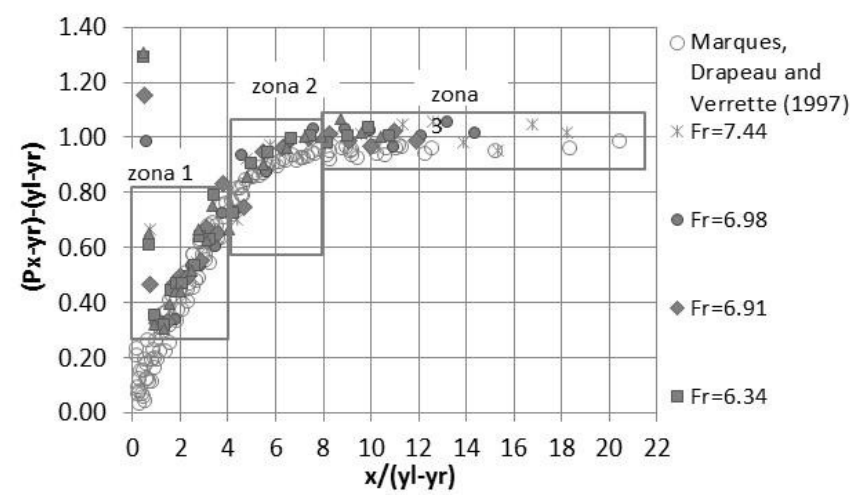

Figure 6. Mean pressure as a function of the distance of the stepped spillway compared to the mean pressure obtained in the smooth chute.

dimensionless curves obtained for pressure fluctuation, according to Equation 8, compared to those obtained by Marques, Drapeau and Verrette (1997).

$\frac{\sigma_{x}}{H_{t}} \frac{y_{l}}{y_{r}}=f\left(\frac{x}{y_{l}-y_{r}}\right)$

Where $\sigma_{x}=$ standard deviation at the point $\mathrm{x}$ in meters of depth of water; $H_{t}=$ loss of head in the hydraulic jump.

Observing Figure 7 it shows that the standard deviation gross values increase with Froude number, ranging from about 0 to 0.35 .

From Figure 8 it can be asserted that the pressure fluctuation values occurring in the present study are maximum at the point closest to the chute, then the flotation undergoes a strong reduction to the approximate position of $1,0\left(y_{l}-y_{r}\right)$, from that point to the distance of about $4.0\left(y_{l}-y_{r}\right)$ the pressure fluctuation still decreases, but more gently. After that the values tend to stabilize. Comparing with the results of Marques, Drapeau and Verrette (1997), it can be observed that, as well as the mean pressures, the pressure fluctuations obtained by the authors at points closesest to the chute are lower than those obtained in the present study. This effect occurs due to the presence of a radius of concordance

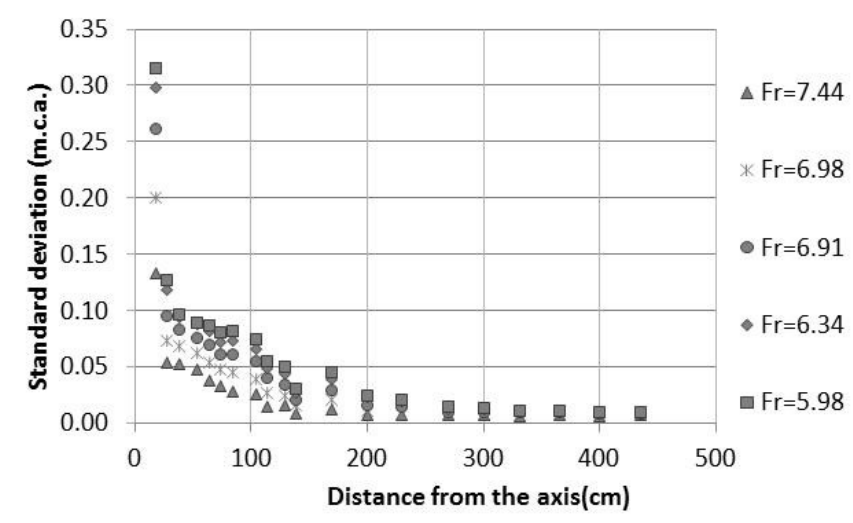

Figure 7. Gross data of standard deviation.

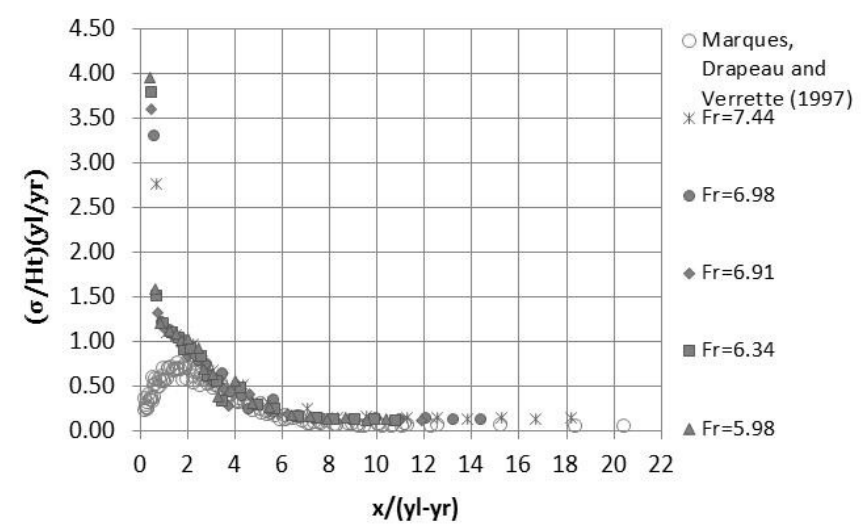

Figure 8. Pressure fluctuation as a function of the distance of the stepped spillway compared to the mean pressure obtained in the smooth chute.

between spillway and stilling basin in the study of Marques, Drapeau and Verrette (1997) which, in addition to the mean pressure values, also significantly reduces the pressure fluctuations at the beginning of the basin. After this, the curves plotted with the data of the present study tend to meet the curves obtained by the authors, presenting very similar patterns. This encounter occurs at the approximate position of $3.0\left(y_{l}-y_{r}\right)$. Figure 9 presents a detail of the same curves focusing on the pressure fluctuations up to the dimensionless value of 1.4 .

\section{SKEWNESS COEFFICIENT}

The analysis of the skewness coefficient of a series of instantaneous pressures indicates how much the extreme values influence the mean. When the coefficient is positive, there are more values of instantaneous pressures highter than the mean, the function is shifted to the right and the value of the mean is elevated. Contrarily, a negative skewness coefficient indicates the greater presence of instantaneous pressure values lower than the mean, which shifts the function to the left and causes a reduction in the mean value. According to Lopardo and Henning (1986), negative skewness means areas of flow detachment from the 
bottom of the channel. The skewness coefficient is presented in Equation 9. Figure 10 shows the values obtained for the skewness as a function of the gross distance in the tests performed and Figure 11 presents the skewness coefficient as a function of the dimensionless distance for the present study in comparison to the results of Marques, Drapeau and Verrette (1997).

$$
A_{d}=\sum_{i=1}^{i=n} \frac{\left(P_{i}-P_{x}\right)^{3}}{n \times \sigma_{x}^{3}}
$$

Where $P_{i}=$ instantaneous pressure at point $\mathrm{x} ; n=$ number of instantaneous pressures measured and $\sigma_{x}=$ standard deviation at position $\mathrm{x}$.

Figure 10 indicates that skewness values range from approximately -0.7 to 0.9 , reaching maximum values at positions between 0 and $100 \mathrm{~cm}$ and minimum values between 100 and $300 \mathrm{~cm}$.

Figure 11 shows the curves obtained for the present study. It can be observed that from the vicinity of the chute until the approximate position of $4.0\left(y_{l}-y_{r}\right)$, the skewness coefficient is positive and presentes the highest value in the sample. This is due to the impact of the water jet in the basin, which causes higher instantaneous pressures. According to Marques, Drapeau and Verrette. (1997), it is also at this point that the flow begins to present a vertical componente to the velocity. From this point on, according to visual observations of the flow combined with the analysis of data acquired by the cited authors, the value of the skewness coefficient begins to reach negative values, due to the fact that the flow begins to separate (detach) from the bottom of the basin, generating lower extreme pressures. This analysis coincides with the conclusions presented by Lopardo and Henning (1986). The minimum skewness coefficient is displayed at the position of about $6\left(y_{l}-y_{r}\right)$ which is the position of the end of the roller in the hydraulic jump. At this point the vertical components of the velocity are more important, and the extreme pressures lower than the mean predominate over the higher ones. From this point on the flow tends to an equilibrium, being parallel to the bottom of the basin, so the skewness coefficient tends to a constant value, close to 0.20 . The coefficient reaches this value in the position of approximately $8\left(y_{l}-y_{r}\right)$, and then, most points tend to stabilize the skewness coefficient at values slightly above zero, no longer suffering the influence of the hydraulic jump. The data obtained by Marques, Drapeau and Verrette (1997) show a similar trend, but at the beginning of the stilling basin to the approximate position of $1.5\left(y_{l}-y_{r}\right)$, the skewness values are higher. From that point on, the two studies have similar curves, the points at which the minimum values of the skewness coefficient occur and where this coefficient again reaches 0 , are practically the same in both studies.

\section{KURTOSIS COEFFICIENT}

The kurtosis coefficient $(\mathrm{k})$ is a dispersion coefficient that indicates how much the values are concentrated in relation to the mean. A distribution with values that are more concentrated in relation to the mean, which makes it more tapered, presents a kurtosis coefficient of less than three. When the coefficient is higher than three, the distribution is more flattened, presenting less concentrated values than the mean. Equation 10 presents

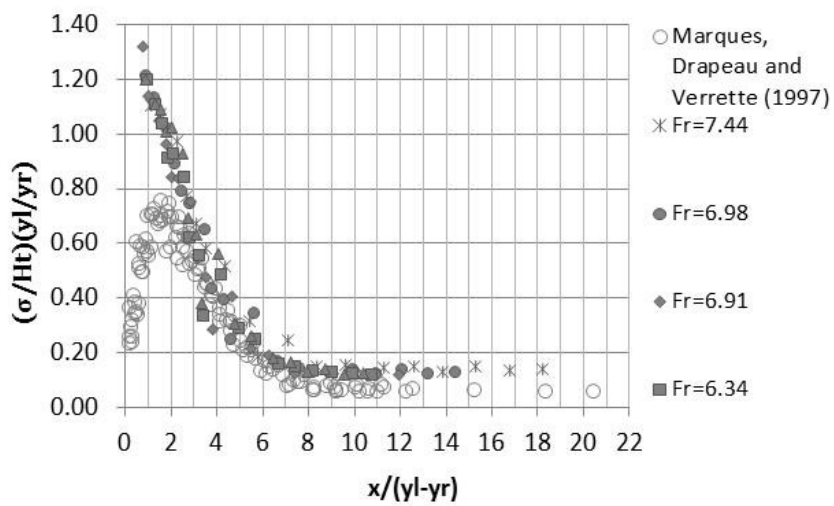

Figure 9. Detail of the pressure fluctuation as a function of the distance of the stepped spillway compared to the mean pressure obtained in the smooth chute.

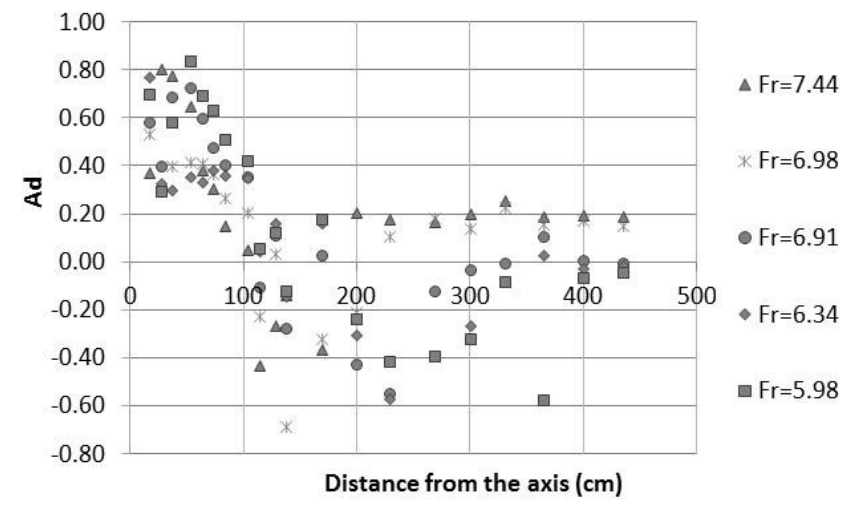

Figure 10. Skewness coefficient data as a function of the (gross) distance of the stepped spillway.

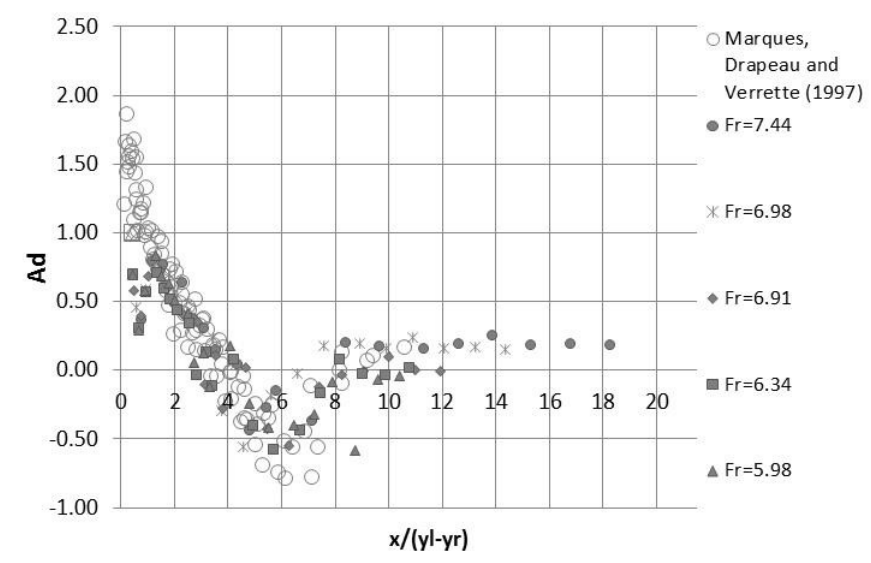

Figure 11. Distribution of skewness coefficients as a function of the distance (dimensionless) of the stepped spillway compared to that obtained in the smooth chute.

the calculation of the kurtosis coefficient. Figure 12 presents the gross values obtained for the kurtosis coefficient in the tests performed and Figure 13 presents the results obtained for the present study compared with the values obtained by Marques, Drapeau and Verrette (1997). 


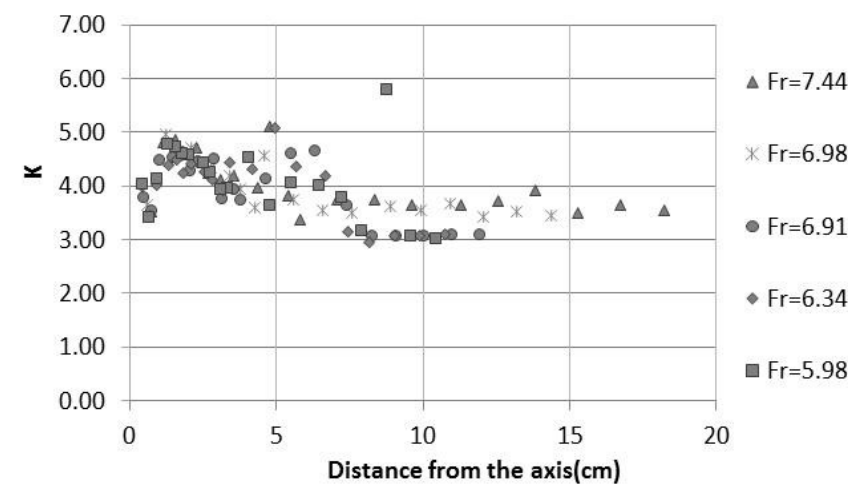

Figure 12. Data on kurtosis coefficients as a function of the (gross) distance of the stepped spillway.

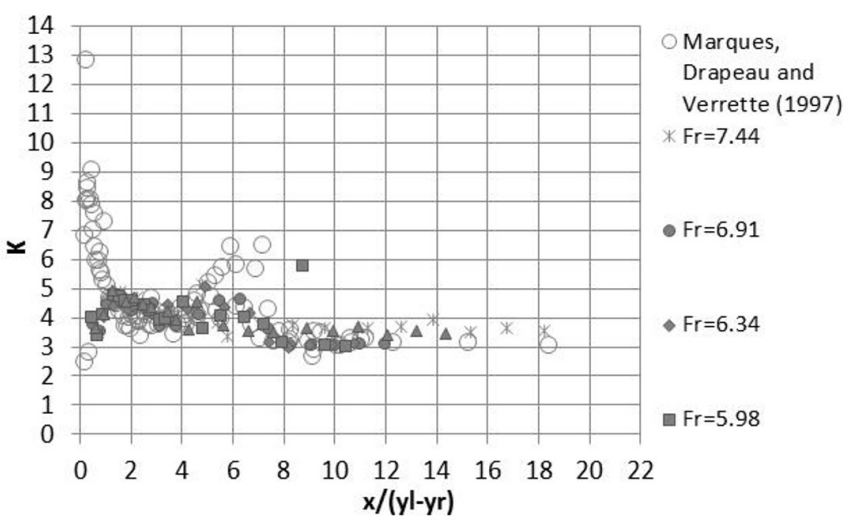

Figure 13. Distribution of kurtosis coefficients as a function of the distance (dimensionless) of the stepped spillway compared to that obtained in the smooth chute.

$k=\sum_{i=1}^{i=n} \frac{\left(P_{i}-P_{x}\right)^{4}}{n \times \sigma_{x}^{4}}$

Figure 12 shows that the values of the kurtosis coefficient vary approximately from 3.0 to 5.0, and a single point with a kurtosis value close to 6.0 can be observed, which may mean an error in the acquisition of the data.

From Figure 13 it can be asserted that, from the beginning of the stilling basin to the approximate position of $1\left(y_{l}-y_{r}\right)$, the values of the kurtosis coefficient obtained for the present work vary between the values of 3.5 and 4, differing significantly from those obtained by Marques, Drapeau and Verrette (1997), which, in this range, are quite dispersed and reach much higher values. From the position of $1\left(y_{l}-y_{r}\right)$ to approximately the position of $4\left(y_{l}-y_{r}\right)$ the curves obtained for the present work meet those obtained by the author with values of kurtosis coefficient close to 4 . After that point until the position of $6\left(y_{l}-y_{r}\right)$, where the flow undergoes a detachment of the bottom tending to find the total height of the flow, the values of kurtosis coefficient found in the present study are a little more dispersed, but still close to 4 . The results from Marques, Drapeau and Verrette (1997) show a greater dispersion, reaching values close to 6 . After this position, the curves resulting from both studies meet again, the values of the kurtosis coefficient suffer a gradual reduction tending to the value of 3 .

\section{CHARACTERISTIC POINTS OF THE HYDRAULIC JUMP}

From the previous analyzes of the longitudinal distributions of mean pressure, pressure fluctuation, skewness and kurtosis coefficients, it was possible to determine some characteristic points of the hydraulic jump and compare with those determined by Marques, Drapeau and Verrette (1997).

The highest pressure fluctuation found was at the position of approximately $0.4\left(y_{l}-y_{r}\right)$, while the position of higher pressure fluctuation found by Marques, Drapeau and Verrette (1997) was $1.75\left(y_{l}-y_{r}\right)$. The positions of flow detachment, end of the hydraulic jump, end of the roller and end of dissipation found for both studies were the same: $4.0\left(y_{l}-y_{r}\right)$ for the beginning of the flow detachment, $6\left(y_{l}-y_{r}\right)$ for the end of the roller and 8.0 $\left(y_{l}-y_{r}\right)$ for the end of the hydraulic jump.

\section{CONCLUSIONS}

Through the statistical analysis of the mean pressures, pressure fluctuations and skewness and kurtosis coefficients presented previously, it was possible to reach some conclusions. The mean pressures are maximum at the nearest point of the stepped chute, differing from the results obtained by Marques, Drapeau and Verrette (1997), for a smooth chute, due to the presence of radius of concordance between chute and stilling basin in the author's essays. Then, the mean pressures decrease sharply and increase again with the distance, coinciding with the data obtained by Marques, Drapeau and Verrette. (1997). The pressures increase to the position of $8.0\left(y_{l}-y_{r}\right)$, where the influence of the hydraulic jump ends, tending to a stabilization. This position coincides with the end of the influence of the hydraulic jump obtained by Marques, Drapeau and Verrette (1997).

The pressure fluctuations, as well as the mean pressures, have their maximum at the closest point to the stepped chute, also differing from the results obtained for studies in smooth chute for the same reason, and decrease with distance. The pressure fluctuation curves obtained by the two studies show the same tendency from the approximate position of $3\left(y_{l}-y_{r}\right)$ on.

Analyzing the skewness coefficient, it can be perceived that the beginning of the flow detachment (where the coefficient begins to reach negative values) occurs at the approximate position of $4\left(y_{l}-y_{r}\right)$. The end of the roller (where the skewness coefficient reaches its minimum value) occurs approximately in the position of $6\left(y_{l}-y_{r}\right)$, and the end of the influence of the hydraulic jump (where the skewness coefficient tends to a stabilization with value close to zero) occurs at the position of about $8.5\left(y_{l}-y_{r}\right)$. These values are the same as those obtained by Marques, Drapeau and Verrette (1997) for the study with smooth chute.

The longitudinal distribution of the skewness and kurtosis coefficients for a hydraulic jump formed downstream of a smooth chute and a stepped chute are similar. The simultaneous analysis of both parameters allows to verify that the pressure data at a given 
position inside the hydraulic jump (less than $\left.8.5\left(y_{l}-y_{r}\right)\right)$ do not follow a normal probability density function $(\mathrm{Ad}=0$ and $\mathrm{k}=3$ ).

\section{REFERENCES}

CONTERATO, E. Determinação de critérios de dimensionamento de soleira terminal em bacia de dissipação a jusante de vertedouro em degraus. 2014. 156 f. Dissertação (Mestre em Engenharia) - Programa de Pós-Graduação em Recursos Hídricos e Saneamento Ambiental, Instituto de Pesquisas Hidráuicas, Universidade Federal do Rio Grande do Sul, Porto Alegre, 2014.

LOPARDO, R. A.; HENNING, R. E. Efectos de las condiciones de ingreso al ressalto sobre el campo de pressiones instantâneas. In: CONGRESSO LATINO AMERICANO DE HIDRÁULICA, 12., 1986, São Paulo. São Paulo: IAHR, 1986. vol. 1, p. 116-127.

MARQUES, M. G.; DRAPEAU, J.; VERRETTTE, J. L. Flutuação de pressão em um ressalto hidráulico com baixo número de froude. Revista Brasileira de Recursos Hidricos, v. 2, n. 2, p. 45-52, 1997.

MEES, A. A. A. Caracterização das solicitações hidrodinâmicas em bacias de dissipação por ressalto hidráulico com baixo número de froude. 2008. 157 f. Dissertação (Mestrado em Engenharia) - Programa de Pós-Graduação em Recursos Hídricos e Saneamento Ambiental, Instituto de Pesquisas Hidráuicas, Universidade Federal do Rio Grande do Sul, Porto Alegre, 2008.

PETERKA, A. J. Hydraulic design of stilling basins and energy dissipators. Washington: Govt. Print. Off, 1957.

SANAGIOTTO, D. Características do escoamento sobre vertedouros em degraus de declividade 1V:0,75H. 2003. 118 f. Dissertação (Mestrado em Engenharia) - Programa de Pós-Graduação em Recursos Hídricos e Saneamento Ambiental, Instituto de Pesquisas Hidráuicas, Universidade Federal do Rio Grande do Sul, Porto Alegre, 2003

SCHULZ, H. E.; NÓBREGA, J. D.; SIMÕES, A. L. A.; SCHULZ, H.; PORTO, R. M. Details of hydraulic jumps for design criteria of hydraulic structures. In: SCHULS, H. E. (Org.). Hydrodynamics - concepts and experiments. Rijeka: InTech, 2015. v. 1, p. 73-116.

SIMÕES, A. Considerações sobre a bidráulica de vertedores em degraus: metodologias adimensionais para pré-dimensionamento. 2008. 258 f. Dissertação (Mestrado em Recursos Hídricos e Saneamento Ambiental) - Departamento de Hidráulica e Saneamento da Escola de Engenharia de São Carlos. Universidade de São Paulo, São Carlos, 2008.

TEIXEIRA, E. D. Previsão dos valores de pressão junto ao fundo em bacias de dissipação por ressalto bidráulico. 2003. 113 f. Dissertação (Mestrado em Engenharia) - Programa de Pós-Graduação em Recursos Hídricos e Saneamento Ambiental, Instituto de Pesquisas Hidráuicas, Universidade Federal do Rio Grande do Sul, Porto Alegre, 2003

TOZZI, M. J. Caracterização/ comportamento de escoamento em vertedouros comparamento em degraus. 1992. 302 f. Tese (Doutorado em Hidráulica) - Universidade de São Paulo, São Paulo, 1992.

\section{Authors contributions}

Carolina Kuhn Novakoski: data collection, data analysis and article elaboration.

Eliane Conterato: article elaboration, data collection and article review.

Marcelo Marques: work orientation and data analysis.

Eder Daniel Teixeira: work orientation and data analysis.

Guilherme Abud Lima: data analysis.

Alexandre Mees: article elaboration, data collection and article review. 